\title{
Pemanfaatan Sistem Informasi Geografis untuk Pemetaan Siswa MTS Muhammadiyah Metro
}

\author{
Mega Desi Diah Ayu 1), Sudarmaji 2), Budi Asmanto ${ }^{3)}$ \\ Fakultas IImu Komputer Universitas Muhammadiyah Metro \\ JI. Gatot Subroto, Yosodadi, Metro Timur, Kota Metro
}

\begin{abstract}
ABSTRAK
Saat ini proses promosi sekolah MTs Muhammadiyah Metro untuk menjaring siswa-siswa baru dilakukan tanpa terorganisir dengan baik sehingga proses promosi akan banyak tidak tepat sasaran dan memerlukan waktu yang cukup lama. Hal ini terjadi dikarenakan sekolah tidak melakukan pemetaan asal-muasal siswa-siswa yang telah (alumni) dan atau sedang bersekolah di MTs Muhammadiyah Metro. Penelitian ini bertujuan untuk membantu proses penjaringan siswa baru semakin optimal Dengan memanfaatkan teknologi Sistem Informasi Geografis (GIS), pengelolaan data alamat siswa dan alumni dapat terkomputerisasi dan dapat ditampilkan dalam bentuk peta digital (maps) dengan memanfaatkan Google Maps API untuk visual yang lebih jelas. Model pengembangan prototipe diterapkan dalam proses pengembangan sistemnya. Penelitian ini berhasil mengembangan prototipe sistem infomasi geografis sesuai dengan requirement yang telah diidentifikasi dengan pihak sekolah.
\end{abstract}

Kata Kunci - Google Maps API, MTs Muhammadiyah Metro, Model Pengembangan Prototipe, Sistem Informasi Geografis

\section{Pendahuluan \\ Madrasah}

Tsanawiyah

(MTs)

Muhammadiyah Metro merupakan salah satu sekolah yang ada di provinsi Lampung dengan jumlah keseluruhan murid adalah 178 siswa pada tahun ajaran 2017/2018. Dalam perkembangannya, proses promosi sekolah MTs Muhammadiyah Metro untuk menjaring siswa-siswa baru dilakukan tanpa terorganisir dengan baik sehingga proses promosi akan banyak tidak tepat sasaran dan memerlukan waktu yang cukup lama. Permasalahan ini akan berpengaruh terhadap kinerja proses pendaftaran siswa baru untuk mendapatkan target jumlah siswa yang diharapkan. Hal ini terjadi dikarenakan sekolah tidak melakukan pemetaan asal-muasal siswasiswa yang telah (alumni) dan atau sedang bersekolah di MTs Muhammadiyah Metro.

Perkembangan teknologi sistem informasi pada saat ini telah memberikan banyak kemudahan bagi manusia dalam menyelesaikan permasalahan diberbagai bidang (Arief, 2011; Bachtiar \& Efendi, 2012; Kharistiani \& Ariwibowo, 2013; Kholil, 2017), tidak terkecuali bidang pendidikan. Teknologi sistem informasi dapat dimanfaatkan oleh MTs Muhammadiyah Metro untuk melakukan pengelolaan data siswa dan alumni. Dengan memanfaatkan teknologi Sistem Informasi Geografis (GIS), pengelolaan data alamat siswa dan alumni dapat terkomputerisasi dan dapat ditampilkan dalam bentuk peta digital (maps) ) dengan memanfaatkan Google Maps API untuk visual yang lebih jelas. Proses penyajian tampilan visual diperoleh dari hasil pengelolaan data spasial alamat siswa dan alumni yang bersekolah di MTs Muhammadiyah Metro. Adapun penelitian sebelumnya yang membahas pemanfaatan sistem informasi geografis pada bidang pendidikan adalah penelitian yang dilakukan oleh E. Kharistiani dan E. Ariwibowo (2013) yang memetakan potensi SMA/SMK di Kabupaten Kebumen (Kharistiani \& Ariwibowo, 2013) serta penelitian yang dilakukan oleh Arief (2011) yang memetakan Sekolah Tingkat Pendidikan Dasar Dan Menengah Di Kota Serang (Arief, 2011).

Berdasarkan permasalahan yang dihadapi MTs Muhammadiyah Metro, penelitian ini akan berfokus pada pengembangan aplikasi Sistem Informasi Geogragif (GIS) untuk sekolah MTs Muhammadiyah Metro. Penelitian ini bertujuan untuk membantu Mts Muhammadiyah Metro memahami bagaimana pengembangan aplikasi GIS 
dapat melakukan pemetaan alamat siswa dan alumni. Pemetaan alamat ini akan memperjelas sekolah untuk melihat secara jelas bahwa daerah mana yang memiliki minat terbanyak untuk sekolah di MTs ini. Hal ini akan mempermudah sekolah dalam proses penjaringan siswa-siswa baru untuk memenuhi target jumlah siswa setiap tahunnya.

Penelitian ini terdiri dari lima bab. Bab pertama adalah pendahuluan, yang menggambarkan masalah dan tujuan penelitian. Kedua adalah tinjauan literatur tentang kondisi sekolah MTs dan Sistem Informasi Geografis (GIS).Bab ketiga membahas metodologi yang digunakan pada penelitian ini. Bab selanjutnya, bab keempat akan menampilkan hasil analisis dan pengembangan aplikasi serta bab terakhir adalah kesimpulan.

\section{TINJAUAN PUSAKA}

\section{A. Sistem Informasi Geografis (GIS)}

Sistem informasi geografis (GIS) merupakan merupakan perangkat lunak yang dapat digunakan untuk proses pemasukan (input), penyimpanan (store), manipulasi, menampilkan, dan mengeluarkan informasi (output) geografis berikut dengan atribut-atributnya (Prahasta, 2002). Teknologi Sistem Informasi Geografis dapat digunakan untuk investigasi ilmiah,pengelolaan sumberdaya, perencanaan, pembangunan, kartografi dan perencanaan rute (Ali, Saeed, \& Fageeri, 2017; Kholil, 2017).

Berdasarkan cara pengelolaannya, sistem informasi goegrafis dibagi menjadi dua yaitu sistem manual (analog) dan sistem otomatis (berbasis digital). Sistem informasi manual biasanya menggabungkan beberapa data seperti peta, lembar transparansi untuk tumpang susun (overlay), foto udara, laporan statistic dan laporan survey lapangan yang dikompilasi dan dianalisis secara manual. Sedangkan sistem informasi geografis otomatis memanfaatkan computer sebagai sistem pengelah data melalui proses giditasi. Sumber data digital dapat berupa citra satelit atau foto udara digital serta foto udara yang terdigitasi. Data lain dapat berupa peta dasar terdigitasi (Budianto, 2016; Prahasta, 2002).

John E. Harmon dan Steven J. Anderson (2003) menganalisa komponenkomponen dari sistem informasi geografis (GIS) adalah sebagai berikut (Prahasta, 2002).
a) Sumber Daya Manusia
b) Aplikasi Sistem Informasi Geografi
c) Data
d) Perangkat Keras (Hardware)
e) Perangkat Lunak (Software)

Data Sistem Informasi Geografis (GIS) meripakan bagian penting dari pengembangan sistemnya. Pengumpulan data dapat diperoleh dari berbagai sumber seperti survei lapangan atau wawancara kepada narasumber. Ada tiga jenis instrument data yang dapat diproses ke dalam sistem informasi geografis, yaitu (Munir, 2012).

\section{1) Data vektor}

Data vektor adalah struktur data yang digunakan untuk menyimpan data spasial. Pada data vektor biasanya terdiri dari titik, garis (arch dan polygon. Titik bisa digunakan sebagai lokasi sebua kota atau posisi tower radio. Garis bisa digunakan untuk menunjukkan rute suatu perjalanan atau menggambarkan batasan daerah.Poligon bisa digunakan untuk menggambarkan sebuah danau atau sebuah Negara pada peta dunia.

\section{2) Data raster}

Data raster merupakan jenis gambar digital yang direpresentasikan dengan pixelpixel sebagai unit terkecil. Foto digital seperti foto satelit merupakanbagian dari data raster pada peta. Data raster terdiri dari kolom dan baris, dimana tiap cell menyimpan nilai warna. Data raster disimpan dalam berbagai format seperti TIF, JPEG, BMP dan sebagainya. Perbedaan data vector dan raster dapat dilihat pada Gambar 1.

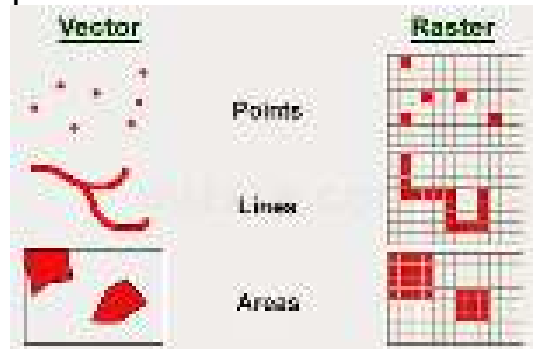

Gambar 1. Contoh Data Vektor dan Data Raster

Gambar 2.

\section{3) Data atribut/tabular}

Data yang terdapat pada ruang atau tempat.Atribut menjelaskan suatu informasi.Biasanya data atribut diperoleh dari statistik, sensus, catatan, lapangan dan data tabular.Data atribut bisa dilihat 
berdasarkan kualitas (misalkan tinggi pohon) dan kuantitasnya(misalkan jumlah pohon).Contoh data atribut misalkan jenis vegetasi, populasi, luasan, kode pos, dan sebagainya.

\section{B. Peta}

Peta merupakan suatu sarana penyimpanan yang merepresentasikan permukaan bumi pada sebuah bidang datar dengan skala tertentu, dimana permukaan bumi sebenarnya tidak selalu datar dan ukuran luasnya adalah melengkung (Budianto, 2016; Munir, 2012). Sehingga dapat dikatakan bahwa dengan menggunakan peta, permukaan bumi seperti letak suatu wilayah, jarak antarkota, lokasi pegunungan, sungau jalan raya, bandara dan permukaan bumi lainnya dapat dilihat dengan mudah penampakannya. Ketampakan yang digambar pada peta dapat dibagi menjadi dua yaitu ketampakan alami dan ketampakan buatan manusia (budaya).

Selaras dengan perkembangan teknologi, peta juga berkembang ke arah digital (digital maps) yang merepresentasikan permukaan bumi yang diolah dengan menggunakan bantuan teknologi komputer. Data yang digunakan pada peta digital juga berupa data digital yang biasanya dibuat dengan menggunakan bantuan software Sistem Informasi Geografi (Prahasta, 2005). IImu yang mempelajari tentang peta dan pemetaan disebut dengan kartografi dan orang yang ahli dalam bidang peta dan pemetaan disebut kartograf. Peta dibedakan menjadi dua jenis, yaitu.

Peta Umum Peta umum adalah peta yang manampilkan bentuk fisik permukaan bumi suatu wilayah.Contohnya adalah peta jalan dan gedung wilayah Metro. Peta Khusus Peta khusus adalah peta yang menampakkan suatu keadaan atau kondisi khusus suatu daerah tertentu atau keseluruhan daerah bumi.Contohnya adalah peta persebaran hasil tambang, peta curah hujan, peta iklim, dan sebagainya.

\section{Google Maps}

Google maps merupakan layanan yang dikembangkan oleh perusahaann google dan dapat diakses secara gratis seperti yang ditunjukkan pada Gambar 2. Layanan ini interaktif, karena di dalamnya peta dapat digeser sesuai keinginan pengguna, mengubah tingkat zoom, serta mengubah tampilan peta. Google maps juga menawarkan peta yang dapat diseret dan gambar setelit untuk seluruh dunia,serta menawarkan rute.

Fitur google maps dapat ditambahkan kedalam aplikasi yang akan dibuat baik berbasis web maupun mobile dengan memanfaatkan Google Maps API. Google Maps API merupakan library JavaScript yang dapat ditambahkan pada koding program yang akan dibangun (Shodiq, 2008). Dengan menggunakan Google Maps $A P I$, kita dapat menghemat waktu dan biaya untuk membangun aplikasi peta digital yang handal, sehingga kita dapat fokus hanya pada data-data yang diperlukan karena data peta-peta dunia sudah ditangani oleh Google.

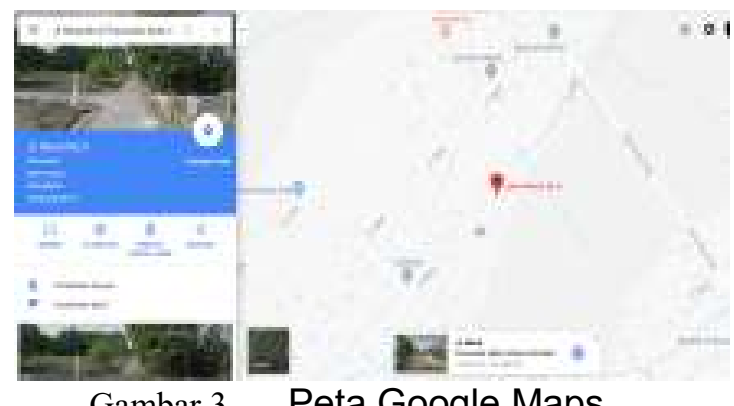

\section{Metode Penelitian}

Penelitian ini mengimplementasikan teori bidang ilmu sistem informasi (SI), khususnya Sistem Informasi Geografis (SIG) dalam proses pengembangannya. Selain itu penelitian ini juga memanfaatkan teknologi Google Maps API untuk mengolah dan menampilkan data-data peta yang dibutuhkan. Metode pengembangan sistem yang diterapkan pada penelitian ini adalah model prototyping.

Model Prototyping merupakan proses iterative dalam pengembangan sistem dimana requirement diubah ke dalam sistem yang bekerja (working system) yang secara terus menerus diperbaiki melalui kerjasama antara user dan analis. Prototype juga bisa dibangun melalui beberapa tool pengembangan untuk menyederhanakan proses (Pressman, 2010). Tahapan-tahapan model prototyping dapat dilihat pada Gambar 3.

\section{A. Communication}

Dalam penelitian ini, komunikasi dengan stakeholder (studi kasus penelitian ini adalah MTs Muhammadiyah Metro) digunakan untuk mengidentifikasi kebutuhan user yang paling mendasar. 
Peneliti akan mewawancarai pihak-pihak MTs Muhammadiyah Metro yang berkaitan dengan proses penerimaan siswa, promosi, serta pimpinan dari sekolah tersebut.

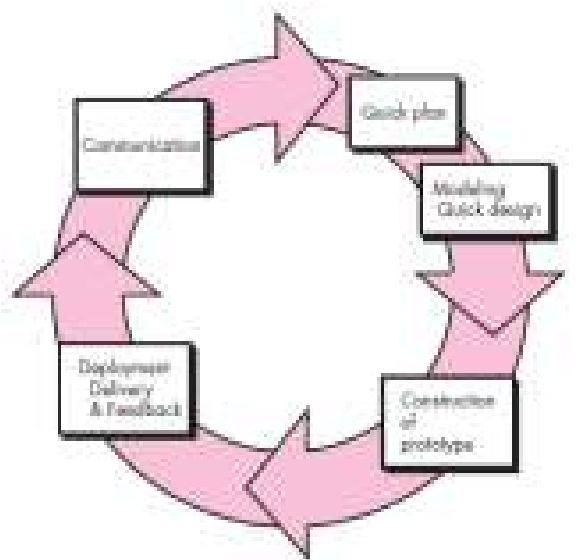

Gambar 4.Model Prototype (Pressman, 2010)

Proses identifikasi kebutuhan pada penelitian ini tidak hanya bergantung pada proses wawancara, observasi dan dokumntasi juga dilakukan untuk mengidentifikasi kebutuhan sistem. Observasi dilakukan dengan melakukan pengamatan secara langsung terkait kegiatan operasional terkait sistem yang sedang berjalan. Sedangkan dokumentasi dilakukan dengan mengumpulkan data dan informasi berupa data-data dokumentasi proses kegiatan seperti buku, jurnal, laporan, atau sejenisnya baik yang ada pada MTs Muhammadiyah Metro maupun luar sekolah yang berkaitan dengan Sistem Informasi Geografis pada bidang pendidikan.

\section{B. Quick Plan dan Modeling Quick Design}

Pembuatan rancangan cepat (quick plan) berdasarkan pada representasi aspek-aspek perangkat lunak yang akan terlihat oleh para end user (misalnya rancangan antarmuka pengguna atau format tampilan). Perancangan sistem pada penelitian ini mencakup desain aliran sistem informasi menggunakan Flowchart, diagram kontext, data flow diagram (DFD), dan Entity Relationship Diagram (ERD) yang dapat menjelaskan aliran data yang diproses sehingga dapat menggambarkan proses aliran data dan informasi pada sistem .

\section{Construction of Prototype}

Rancangan cepat (quick plan) yang telah dibangun menjadi dasar untuk memulai konstruksi pembuatan prototipe. Pengembangan prototipe dilakukan sesuai dengan desain prototipe yang telah dibangun pada tahapan sebelumnya.

\section{Deployment, Delivery \& Feedback}

Prototipe kemudian diserahkan kepada para stakeholder untuk dilakukan evaluasi yang diharapkan stakeholder akan memberikan umpan-balik (feedback) yang akan digunakan untuk memperbaiki spesifikasi kebutuhan. Iterasi terjadi saat pengembangan sistem perlu dilakukan perbaikan sesuai dengan umpan-balik yang telah diberikan oleh stakeholder

\section{HASIL DAN PEMBAHASAN}

Sistem Informasi Geografis berbasis web untuk pemetaan siswa pada MTs Muhammadiyah Metro. Menggunakan bahasa pemrograman PHP, database MySQL dan menggunakan aplkasi dreamweaver cs6. Data yang diolah merupakan data siswa dengan cetak laporan data siswa beserta pemetaan siswa pecarian data siswa dilakukan berdasarkan nama siswa.

\section{A. Analisis Kebutuhan Sistem}

Analisis kebutuhan sistem diperoleh dari berbagai literatur, proses wawancara dengan kepala tata usaha sumber-sumber nlain dari buku yang berkaitan dengan Sistem Informasi Geografis berbasis web untuk pemetaan siswa di MTs Muhammadiyah Metro. Analisis kebutuhan sistem meliputi:

\section{1) Data masukan (input)}

Data masukan (input) yang diperlukan sebagai bahan pembuatan sistem informasi geografis yang meliputi data siswa.

\section{2) Proses (process)}

Admin mengelola data siswa, data pemetaan siswa kemudian sistem akan menyimpan data tersebut kedalam databaseyang semuanya sudah berelasi antara tabel satu dengan tabel yang lain. Sistem ini juga bekerja dalam pencarian data siswa berdasarkan nama siswa dan mencetak laporan data siswa beserta pemetaan siswa yang menggunakan googlemaps.

\section{3) Keluaran (output)}

Keluaran (output) yang dihasilkan oleh sistem adalah laporan data siswa yang mencakup daerah tempat tinggal siswa.

Berdasarkan analisis kebutuhan sistem, diperoleh sepesifikasi sistem yang 
akan diimplementasikan kedalam sistem informasi geografis berbasis web pemetaan siswa, adapun sepesifikasi yang dibutuhkan meliputi.

- Dapat menerima input data siswa, dan wilayah siswa yang berelasi antar tebel secara otomatis.

- Dapat memproses laporan data siswa dan daerah sisw tersebut.

- Dapat melakukan pencarian wilayah siswa secara cepat dan efektif berdasarkan nama.

\section{B. Perancangan sistem}

Dalam merancang suatu sistem diperlukan beberapa tahap untuk menentukan arah sistem tersebut. Proses desain aliran sistem informasi pada penelitian ini menggunakan Flowchart, 2.

Context Diagram, dta flow diagram (DFD), dan Entity Relationship Diagram (ERD) sehingga dapat menjelaskan aliran data yang diproses sehingga dapat menggambarkan proses aliran data dan informasi pada sistem. Gambaran umum sistem yang dibangun dapat dilihat pada Gambar 4.

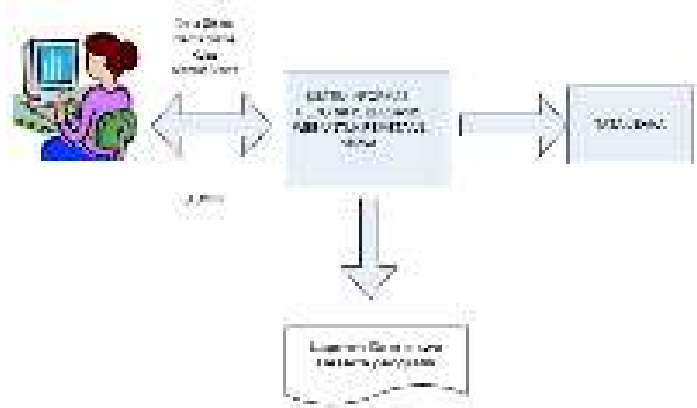

Gambar 5. Gambaran Sistem yang Dibangun

\section{1) Flowchart}

Bagan alir (flowchart) merupakan bagan (chart) yang menunjukan aliran flow didalam program atau prosedur sistem secara logika prosedur sistem yang dibangun yang dapat dilihat pada Gambar 5 .

2) Context Diagram dan Data Flow Diagram (DFD)

Rancangan diagram Context sistem informasi geografis berbasis web untuk pemetaan siswa yang diusulkan dapat dilihat pada Gambar 6.

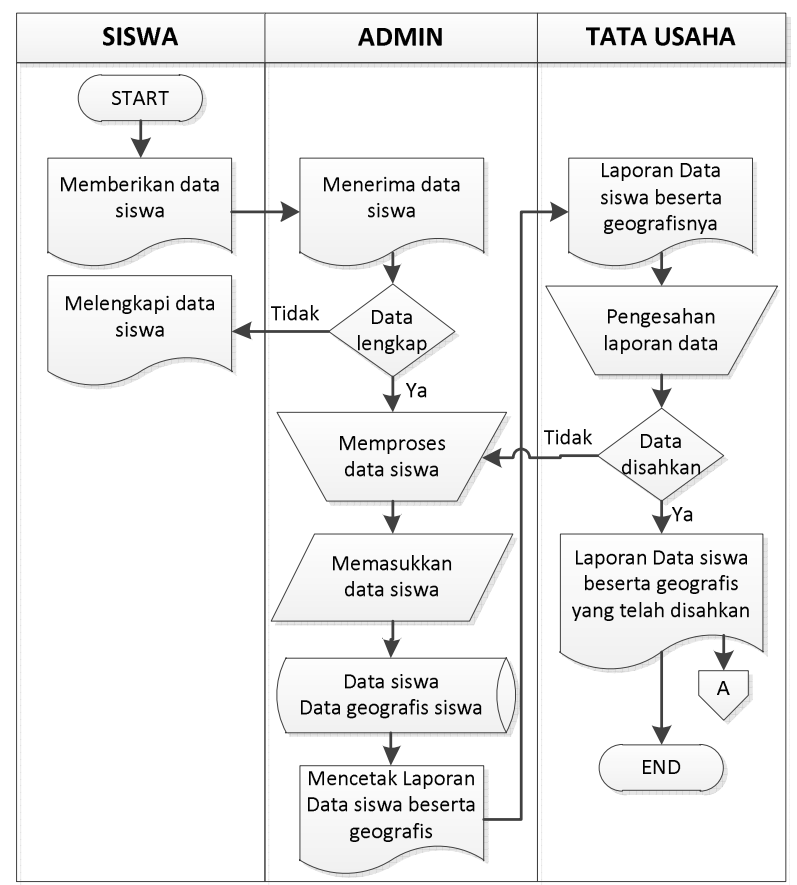

Gambar 6. Rancangan Fowchart Sistem Informasi Geografis Pemetaan siswa

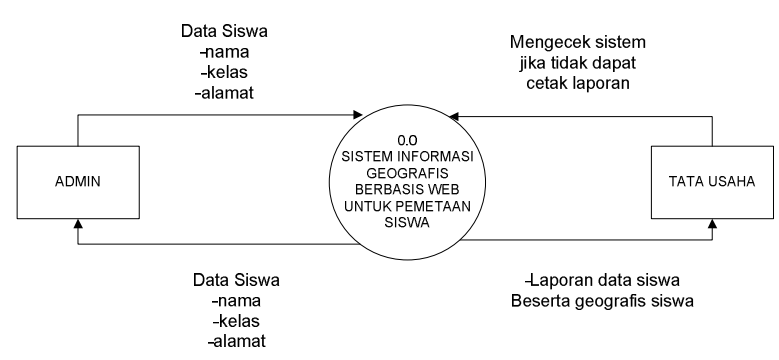

Gambar 7. Diagram kontext

Pada tahapan pemodelan proses ini penulis juga merancang DFD Level 1 tersebut berasal dari turunan DFD kontext, Siswa memberikandata siswa. Pihak admin kemudian menginputkan data dan memetakan siswa tersebut kedalam sistem. Jika data siswatidak lengkap maka kembali kesiswa untuk di lengkapi jika data tersebut lengkap maka akan di proses lalu diinputkan kedalam sistem database.Kemudian diotorisasi diserahkan kepada tata usaha dan pemetaan geografis berhasil baik, selesai. Adapun DFD level 1 dapat dilihat pada gambar 7 . 


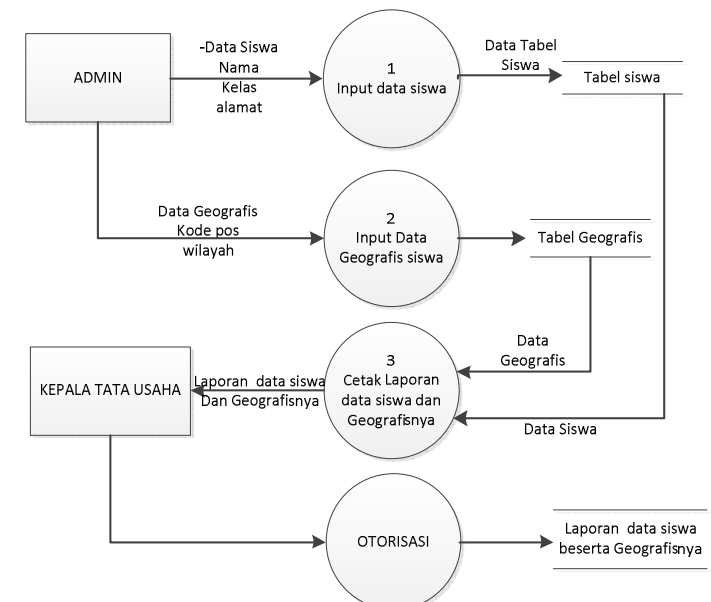

Gambar 8. Rancangan Data Flow Diagram (DFD) Level 1

\section{3) Entity Relationship Diagram (ERD)}

Entity Reletionship Diagram (ERD) adalah suatu model jaringan yang menggunakan susunan data yang di simpan dalam sistem secara abstrak. Rancangan ERD file database dan hubungan antar entitas pada Gambar 8.

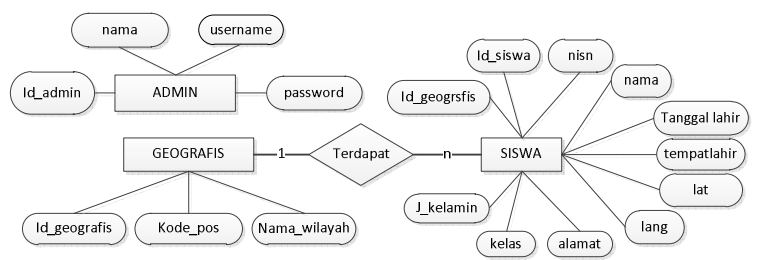

Gambar 9. Entity Relationship Diagram

\section{Pengembangan Sistem}

Tahap pengembangan sistem tidak lepas dari kebutuhan perangkat lunak dan perangkat keras yang dipakai. Tabel 1 menampilkan spesifikasi perangkat keras dan lunak yang digunakan pada pengembangan sistem ini.

Tabel 1. Kebutuhan Perangkat lunak dan Keras

\begin{tabular}{|c|c|}
\hline $\begin{array}{c}\text { Perangkat Lunak } \\
\text { (Software) }\end{array}$ & $\begin{array}{c}\text { Perangkat Keras } \\
\text { (Hardware) }\end{array}$ \\
\hline Dreamweaver cs6 & $\begin{array}{c}\text { Processor intel Core } \\
\text { i3 }\end{array}$ \\
\hline XAMMP & $\begin{array}{c}\text { Memory (RAM) 2 } \\
\text { GB }\end{array}$ \\
\hline Google Maps & Hard Disk 500 GB \\
\hline
\end{tabular}

Hasil yang diperoleh dari pengembangan sistem adalah sebuah prototipe sistem informasi geografis dengan rincian sebagai berikut.

1) Database sistem

Database sistem pada penelitian ini menggunakan penamaan db_siswa_mts yang berisikan tiga table, yaitu tabel admin , tabel geografis, dan tabel siswa. Tabel admin berfungsi untuk menyimpan data karyawan sekolah MTs Muhammadiyah Metro yang ditunjuk sebagai administrator dengan tampilan seperti yang ditunjukkan pada Gambar 9.

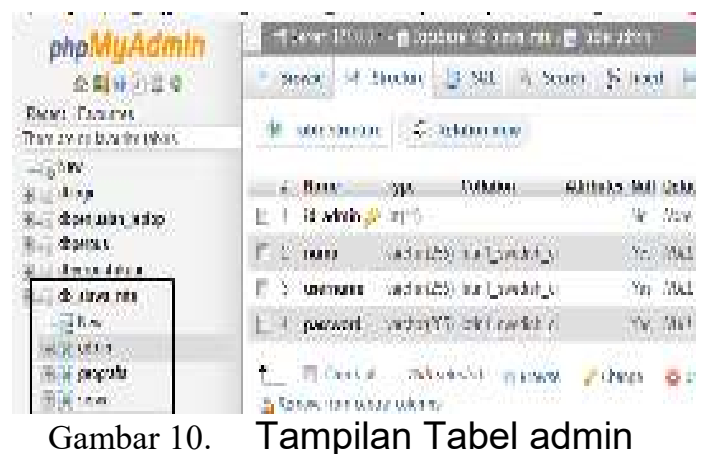

Tabel geografis berfungsi untuk menyimpan data geografis wilayah Lampung dan sekitarnya seperti yang ditunjukkan pada Gambar 10. Sedangkan Tabel siswa berfungsi untuk menyimpan data umum siswa yang dimasukkan oleh administrator seperti yang ditunjukkan pada Gambar 10.
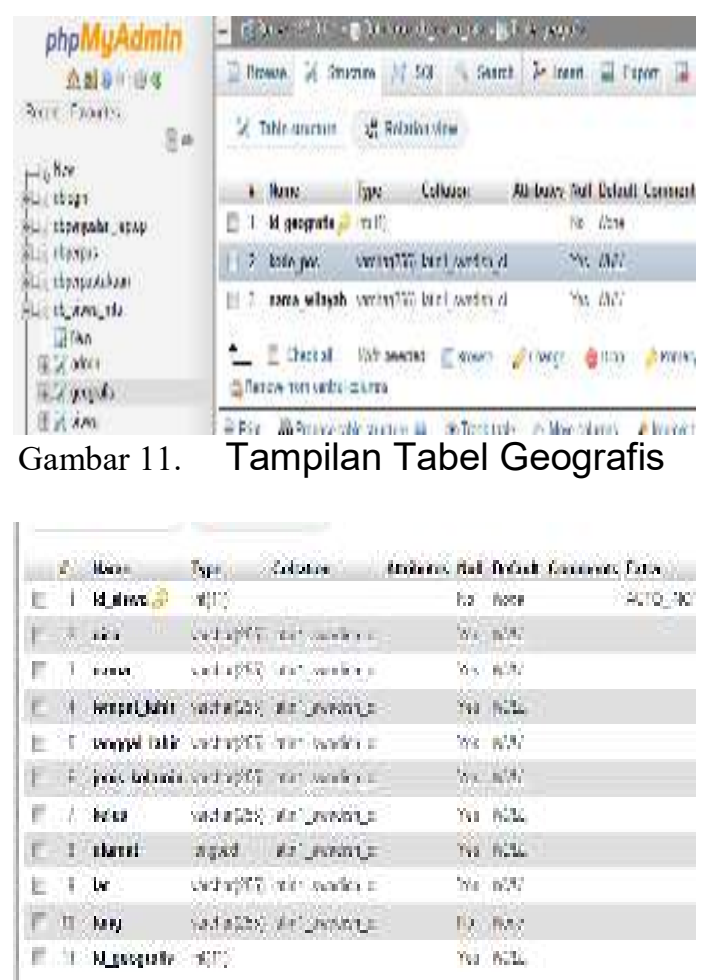

Gambar 12. Tampilan Tabel siswa

a) Halaman Depan Administrator

Halaman depan administrator (dapat dilihat pada Gambar 12) ini merupakan halaman muka sistem informasi geografis 
Mts Muhammadiyah Metro. Menu ini berfungsi sebagai tempat untuk memilih menu yang ingin digunakan seperti ingin menginputkan data siswa, mencari data siswa atau mencetak laporan Namun sebelum masuk ke halaman administrator, seorang admin perlu melakukan login terlebih dahulu.

\section{b) Menu Manajemen Data Siswa}

Tampilan ini berfungsi sebagai manajemen data siswa dari tampilan form penginputan data siswa meliputi NISN, Nama, tempat tanggal lahir, jenis kelamin, kelas, dan alamat seperti yang ditunjukkan pada Gambar 13 serta tampilan data siswa yang telah dimasukkan kedalam sistem seperti pada Gambar 14.

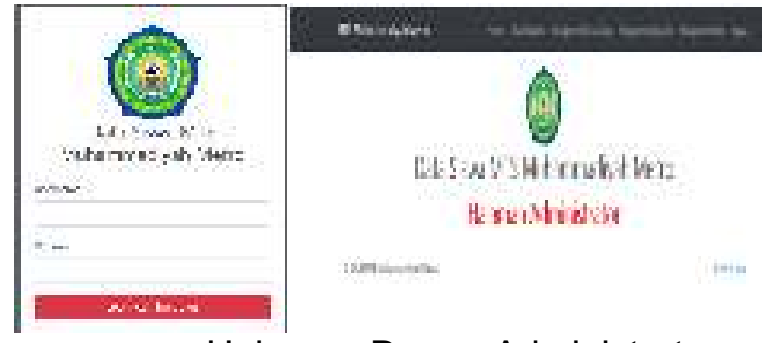

Gambar 13. Halaman Depan Administrator

\section{Whitrretrithr}

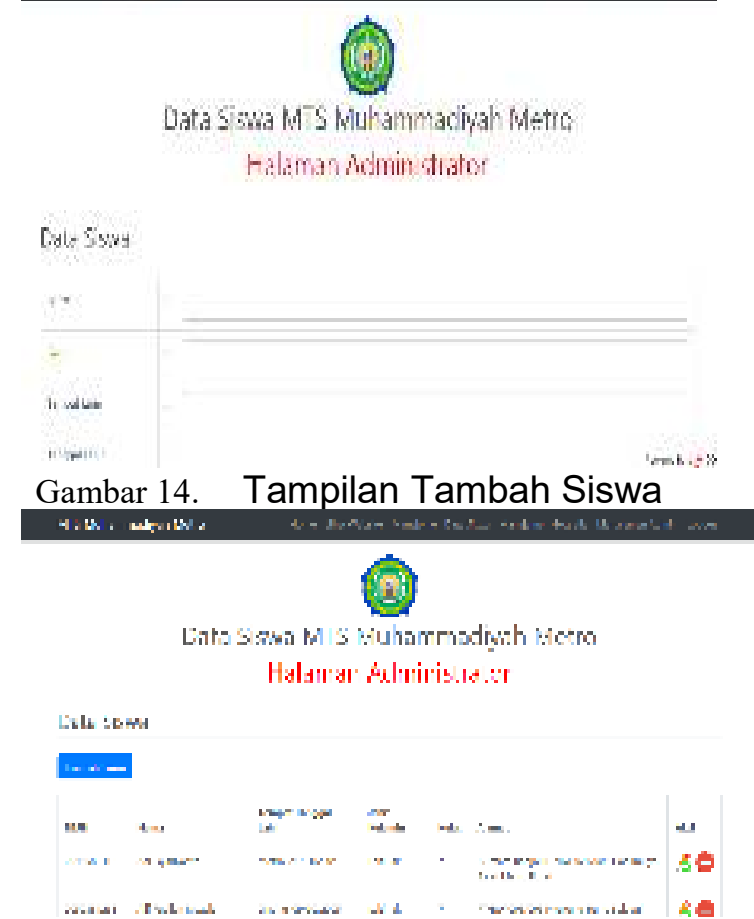

Gambar 15. Tampilan Manajemen Data Siswa

c) Menu Manajemen Geografis

Manajemen Geografis merupakan menu yang digunakan untuk data-data geografis meliputi proses penginputan data geografis (dapat dilihat pada Gambar 15) sampai proses menampilkan data geografis yang telah dimasukkan ke dalam sistem (dapat dilihat pada Gambar 16).
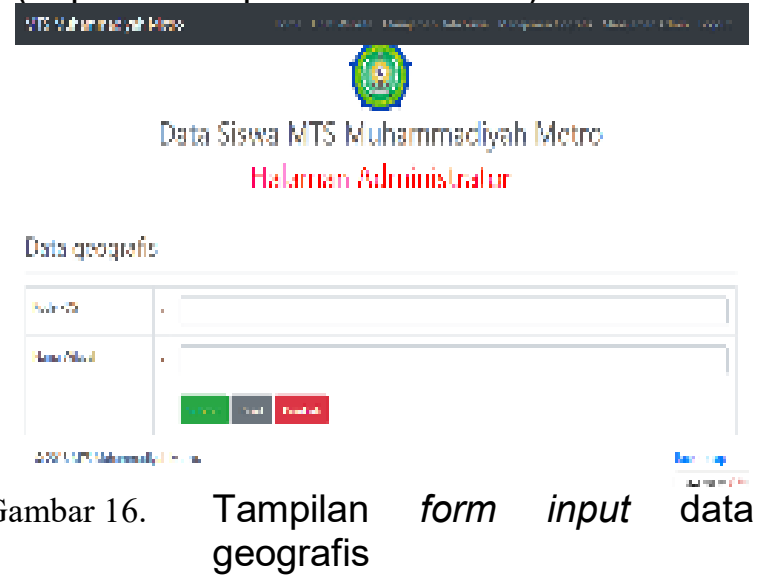

\section{d. Menu Daftar Siswa}

Menu ini berfungsi untuk menampilkan seluruh data siswa yang bersekolah di MTs Muhammadiyah Metro dalam bentuk Google Maps seperti yang dapat dilihat pada Gambar 17. Dalam menu ini juga disediakan menu pencarian data berdasarkan nama siswa (dapat dilihat pada Gambar 18) dan menampilkan rincian informasi yang dimiliki siswa yang dicari untuk proses pencetakan ke hardcopy seperti pada Gambar 19.

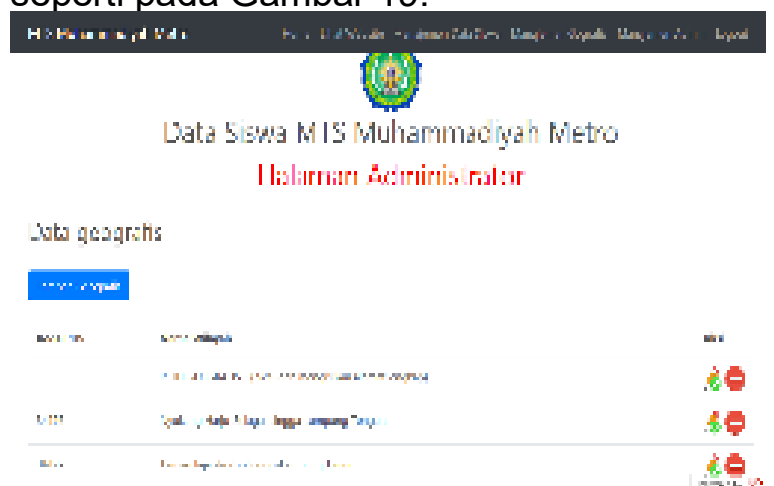

Gambar 17. Tampilan data geografis

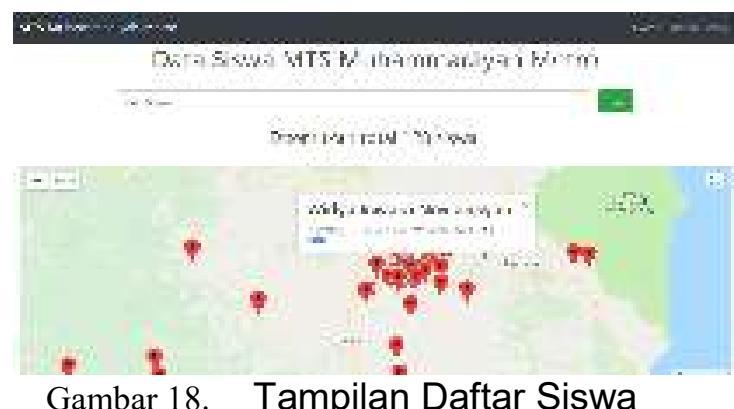

D. Deployment, Delivery \& Feedback

Setelah prototipe dirasa sudah cukup memenuhi requirement yang dibutuhkan oleh MTs Muhammadiyah Metro, selanjutnya prototipe diserahkan (delivery) kepada para stakeholder untuk dilakukan evaluasi yang diharapkan akan 
memberikan umpan-balik (feedback). Proses delivery prototipe dilakukan dengan melakukan demonstrasi prototipe di hadapan stakeholder. Umpan balik yang didapat dari proses ini peneliti rangkum dalam bentuk kelebihan dan kekurangan dari sistem ini. Kekurangan dari sistem ini dapat digunakan untuk melakukan iterasi pengembangan sistem sesuai dengan metode pengembangan sistem yang digunakan (Pressman, 2010).

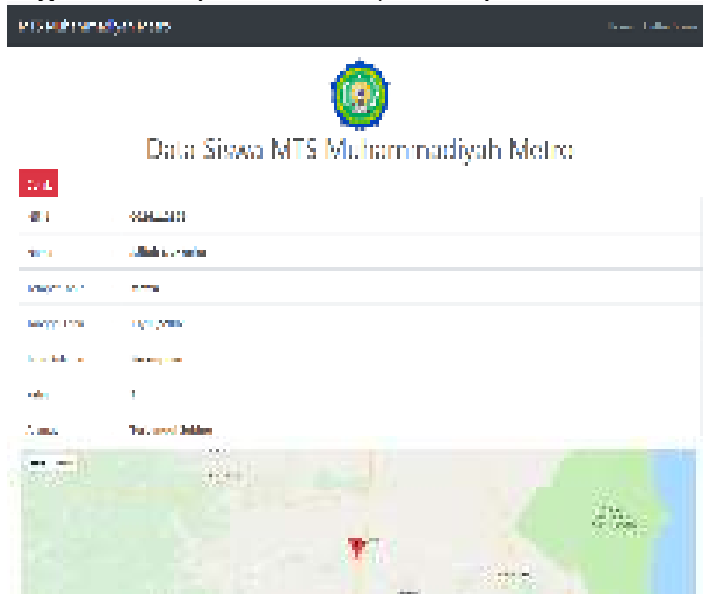

Gambar 19. Tampilan Rincian Informasi Siswa

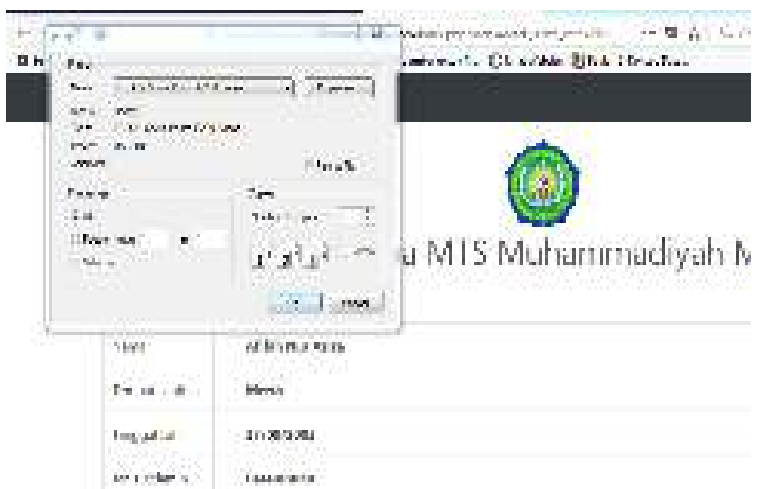

Gambar 20. Tampilan Laporan Daftar Siswa dan geografisnya

1) Kelebihan dari sistem informasi geografis siswa

- Dapat memepermudah staf Tata Usaha dalam penyimpanan data siswa

- Dapat mempermudah pencarian lokasi geografis siswa karna lebih efesien dan mudah.

- Dapat memepermudah dalam pencarian lokasi untuk bahan promosi sekolah.

- Dapat mempermudah dalam pembuatan laporan

2) Kekurangan Program

- Hanya bisa mengakses siswa saja

- Rancangan antar muka masih sederhana
Sistem ini hanya dapat dibuka pada operasi system berbasis windows yang akan digunakan untuk memperbaiki spesifikasi kebutuhan.

\section{KESIMPULAN}

Dari hasil penelitian yang telah dilakukan pada MTs Muhammadiyah Metro dapat disimpulkan bahwa berdasarkan hasil dari analisa, Sistem Informasi Geografis siswa berbasis web untuk pemetaan siswa serta implementasi sistem Informasi Geografis siswa di Sekolah MTs Muhammadiyah Metro menggunakan fitur Google Maps telah berhasil dibangun dengan domain "http://geografissiswamts.000webhostapp.c om".

Hasil uji coba menunjukkan bahwa sistem Online berhasil memenuhi semua kebutuhan yang diidentifikasi di awal penelitian. Beberapa umpan balik dari proses delivery dapat digunakan untuk iterasi pengembangan. Dalam implementasi sistem online ini, Google Maps API sangat membantu dalam proses menyediakan dan menampilkan informasi data alamat siswa di MTs Muhammadiyah Metro secara visual peta digital.

Dengan mengimplementasikan sistem informasi geografis (SIG) ke dalam sistem, maka dapat menampilkan luaran (output) berupa gambaran visual peta digital (google maps). Hal ini akan memudahkan pihak sekolah MTs Muhammadiyah Metro dalam mengidentifikasi daerah mana yang banyak bersekolah di Mts Muhammadiyah Metro. Promosi bias lebih difokuskan pada daerahdaerah yang memiliki banyak siswa yang bersekolah di MTs Muhammadiyah Metro. Sebaliknya, untuk daerah yang kurang dan atau bahkan tidak ada siswa yang berminat bersekolah di MTs Muhammadiyah metro bisa dilakukan kunjungan ke sekolahsekolah dasar sebagai sarana pengenalan MTs Muhammadiyah Metro. Sehingga proses promosi pendaftaran siswa baru dapat dilakukan secara optimal dan tepat sasaran.

\section{DAFTAR PUSTAKA}

[1] Ali, T. A. T., Saeed, R. A., \& Fageeri, S. O. (2017). Web-based GIS Business Hotels Tourism Sites in Khartoum, Sudan. Proceedings - 2017 International Conference on Communication, Control, Computing and Electronics Engineering, ICCCCEE 2017, (January). 
https://doi.org/10.1109/ICCCCEE.201 7.7867683

[2] Arief. (2011). Geografis Pemetaan Sekolah Tingkat Pendidikan Dasar Dan Menengah Di Kota Serang. Jurnal Masyarakat Informatika, 2(3).

[3] Bachtiar, A. M., \& Efendi, R. (2012). SISTEM INFORMASI GEOGRAFIS PEMETAAN FASILITAS UMUM DI KABUPATEN SUMEDANG BERBASIS WEB. Jurnal Ilmiah Komputer Dan Informatika (KOMPUTA), Volume. I(ISSN :20899033), 71-78.

[4] Budianto, E. (2016). Sistem Informasi Geografis dengan Quantum Gis. Yogyakarta: C.V ANDI OFFSET.

[5] Kharistiani, E., \& Ariwibowo, E. (2013). Sistem Informasi Geografis Pemetaan Potensi SMA/SMK Berbasis Web (Studi Kasus: Kabupaten Kebumen. Jurnal Sarjana Teknik Informatika, 1, 9.

[6] Kholil. (2017). Pemanfaatan Sistem
Informasi Geografis (Sig) Dalam Aplikasi Pelaporan Dan Pelacakan Kejahatan Berbasis Android the. Jurnal Teknologi Informasi Dan Komunikasi, 6(1), 51-58.

[7] Munir, A. (2012). IImu Ukur Wilayah dan Sistem Informasi Geografi. Jakarta: KENCANA.

[8] Prahasta, E. (2002). Konsep -Konsep Dasar Sistem Informasi Geografis. Bandung: Informatika.

[9] Prahasta, E. (2005). Sistem Informasi Geografis: Aplikasi Pemrograman MapInfo. Bandung: Informatika.

[10] Pressman, R. S. (2010). Software Engineering A Practitioner's Approach 7th Edition. In Software Engineering $A$ Practitioner's Approach 7th Ed - Roger $S$. Pressman. https://doi.org/10.1017/CBO97811074 15324.004

[11] Shodiq, A. (2008). Pemrograman Google Maps API. Sisfo-Jurnal Sistem Informasi. 